\title{
Selection of reference genes for expression analyses of red-fleshed sweet orange (Citrus sinensis)
}

\author{
T.T. Pinheiro ${ }^{1,2}$, D.S. Nishimura ${ }^{1}$, F.B. De Nadai $^{2}$, A. Figueira ${ }^{1}$ and R.R. Latado ${ }^{2}$ \\ ${ }^{1}$ Laboratório de Melhoramento de Plantas, Centro de Energia Nuclear na Agricultura, \\ Universidade de São Paulo, Piracicaba, SP, Brasil \\ ${ }^{2}$ Centro APTA Citros "Sylvio Moreira", Instituto Agronômico, Cordeirópolis, SP, Brasil
}

Corresponding author: R.R. Latado

E-mail: rrlatado@gmail.com

Genet. Mol. Res. 14 (4): 18440-18451 (2015)

Received August 11, 2015

Accepted October 16, 2015

Published December 23, 2015

DOI http://dx.doi.org/10.4238/2015.December.23.32

ABSTRACT. Red-fleshed oranges (Citrus sinensis) contain high levels of carotenoids and lycopene. The growing consumer demand for products with health benefits has increased interest in these types of Citrus cultivars as a potential source of nutraceuticals. However, little is known about the physiology of these cultivars under Brazilian conditions. Transcriptome and gene expression analyses are important tools in the breeding and management of red-fleshed sweet orange cultivars. Reverse transcription quantitative polymerase chain reaction is a method of quantifying gene expression, but various standardizations are required to obtain precise, accurate, and specific results. Among the standardizations required, the choice of suitable stable reference genes is fundamental. The objective of this study was to evaluate the stability of 11 candidate genes using various tissue and organ samples from healthy plants or leaves from citrus greening disease (Huanglongbing)-symptomatic plants of a Brazilian red-fleshed cultivar ('Sanguínea de Mombuca'), in order to select the most suitable reference gene for investigating gene expression under these conditions. geNorm and NormFinder identified genes that encoded translation initiation 
factor 3 , ribosomal protein $\mathrm{L} 35$, and translation initiation factor $5 \mathrm{~A}$ as the most stable genes under the biological conditions tested, and genes coding actin $(A C T)$ and the subunit of the PSI reaction center subunit III were the least stable. Phosphatase, malate dehydrogenase, and $A C T$ were the most stable genes in the leaf samples of infected plants.

Key words: Gene expression; Stability; Carotenoid; Citrus

\section{INTRODUCTION}

Orange juice is globally the most consumed fruit drink, and accounts for $35 \%$ of the global juice market. The production regions of Florida (USA) and São Paulo (Brazil) are responsible for $81 \%$ of global orange juice production. Orange juice has important nutritional properties, is rich in vitamins, minerals, and fiber, and its components that can reduce the risk of many chronic diseases (Neves et al., 2010). As an important source of flavonoids and anti-oxidative compounds, orange juice is considered highly beneficial to cardiovascular health (Aptekmann and Cesar, 2013; Silveira et al., 2014).

Red-fleshed sweet orange cultivars (Citrus sinensis) produce attractive fruits with a reddish pulp due to the presence of lycopene, a carotenoid that is absent in yellow-pulped oranges (Liu et al., 2007). The cultivar 'Sanguínea de Mombuca' probably originated in Brazil as a spontaneous mutant; this genotype produces fruits that exhibit early maturity and a red pulp, which result in a juice with an intense and attractive color and is suitable for industrial processing (Latado et al., 2008). Currently, 'Sanguínea de Mombuca' is only cultivated in Brazil, but there is great potential for its cultivation to be expanded.

Citrus species are susceptible to a large number of pathogens, and citrus greening disease (Huanglongbing, HLB) is currently one of the greatest threats to sweet orange production in Brazil and the USA (Gottwald, 2010). The presumed causal agents of HLB are the Gram-negative bacteria Candidatus liberibacter asiaticus, Candidatus liberibacter africanus, and Candidatus liberibacter americanus, which are transmitted by psyllids (Bové, 2006) or by grafting with contaminated buds (Halbert and Manjunath, 2004). Symptoms of HLB include severe chlorosis and the development of asymmetric leaves, excessive fruit drop, and possible plant death. Fruits from infected trees are in general irregularly shaped, and yield an unpleasant juice and aborted seeds (Bové, 2006). HLB infects all Citrus species including sweet oranges and mandarins (C. reticulata), which are two of the most cultivated species and have the greatest commercial importance, and, coincidentally, are among the most susceptible genotypes (Folimonova et al., 2009; Shokrollah et al., 2009).

Transcriptome analyses are fundamental in elucidating the roles of genes and regulatory networks in various biological processes, such as different stages of development (Pattison et al., 2015) and interactions with the environment (Shen et al., 2011). Reverse transcription quantitative polymerase chain reaction (RT-qPCR) has become the method of choice to investigate gene expression, because of its sensitivity, specificity, and ease of use (Gachon et al., 2004). The use of RT-qPCR requires a series of standardizations to produce robust and reliable results. The main standardizations include the concentration, integrity, and quality of the original RNA sample, the efficiency of the reverse transcription reaction, and the enzymatic amplification efficiency of the reverse-transcript reaction (Huggett et al., 2005; Bustin et al., 2009). Among the fundamental elements required for a reliable RTqPCR, the reference genes employed to standardize the RNA concentration and normalize the data are considered the most critical (Schmittgen and Zakrajsek, 2000). 
Usually, reference genes encode for proteins with a constitutive expression, such as actin $(A C T)$ (Liu et al., 2010), glyceraldehyde 3-phosphate dehydrogenase (GAPDH) (Galli et al., 2013), elongation factors (EF) (Bomal et al., 2008), ubiquitin (UBQ) (Lin and Lai, 2010), and tubulin (TUB) (Die et al., 2010), which are all part of the basic metabolism of plant cells, and therefore are assumed to exhibit little variation in expression under different ontogenetic or biological conditions. The instability of reference gene expression may result in an over- or under-estimation of target gene expression (Dheda et al., 2005). Gene expression studies in animals (Small et al., 2008) and plants, including Citrus species (Kou et al., 2012; Mafra et al., 2012; Yan et al., 2012), have demonstrated that even genes considered to have a constitutive expression exhibit variation in expression under different experimental conditions, which requires an a priori determination of the stability of reference gene candidates, depending upon the conditions to be evaluated.

To determine the stability of reference genes, software has been developed that employs algorithms to identify, with statistical rigor, the most stable reference genes in specific biological conditions, including geNorm (Vandesompele et al., 2002) and NormFinder (Andersen et al., 2004). geNorm identifies the pair of the most stable genes, and calculates the mean stability value of expression (M) and the mean pairwise variation (V) (Vandesompele et al., 2002); it provides the ideal number of reference genes that must be used for each experimental condition. Similarly, NormFinder identifies the most stable genes, which are those that exhibit the lowest variation within and between treatments (Andersen et al., 2004).

Therefore, the objective of this study was to evaluate the stability of 11 candidate genes using various tissue and organ samples from healthy 'Sanguínea de Mombuca' plants and from leaves of HLB-symptomatic plants, in order to select the most suitable reference genes for investigating gene expression under these conditions.

\section{MATERIAL AND METHODS}

\section{Plant material}

Six healthy 'Sanguínea de Mombuca' plants obtained from rooted cuttings were cultivated in 10-L pots containing a 1:1 sand/soil mixture for three years. Two additional plants were infected with $C$. liberibacter asiaticus by grafting infected buds. Six months after budding, infection was confirmed by PCR following the method described by Coletta-Filho et al. (2010). Tissues from these plants were used in two experiments to analyze the stability of the reference genes. In the first, the candidate reference genes were analyzed using samples from leaves, flowers, stems, roots, seeds, the flavedo, and fruit pulp from healthy plants; in the second, leaves of infected plants were used to test gene reference stability.

\section{Reference gene search and primer design}

Gene sequences were retrieved from the Citrus sinensis database (ftp://occams.dfci. harvard.edu/pub/bio/tgi/data/Citrus_sinensis/). The following genes were identified by their tentative consensus (TC) identifiers and chosen according to information described in the literature: actin (ACT, TC219), elongation factor (EF, TC877), glyceraldehyde 3-phosphate dehydrogenase (GAPDH, TC6953), malate dehydrogenase $(M D H, T C 623)$, phosphatase (PHS, TC1013), PSI reaction center subunit III (PSI, TC9462), ribosomal protein L35 (Rp/35, TC12848), translation initiation factor 3 (IF3, TC2703), translation initiation factor 5A (IF5A, TC17010), ubiquitin (UBQ, 
TC5210), and tubulin (TUB, TC3994). Primers were developed using Primer3 (Rozen and Skaletsky, 2000), and their quality was confirmed using NetPrimer (http://www.premierbiosoft.com/netprimer).

\section{RNA extraction and cDNA synthesis}

Total RNA was extracted using the protocol described by Tao et al. (2004), with minor modifications. Approximately 5-8 $\mathrm{g}$ fruit pulp and 1-2 $\mathrm{g}$ of the remaining tissues or organs were used for extraction. Total RNA was quantified in an Ultrospec 1100 spectrophotometer (Amersham Biosciences, Piscataway, NJ, USA) and RNA integrity was examined by gel electrophoresis. The absence of genomic DNA contamination was confirmed by PCR using primers specific for the Rp/35 gene (sequence described in Table 1). cDNA was synthesized from $2 \mu \mathrm{g}$ DNase-treated

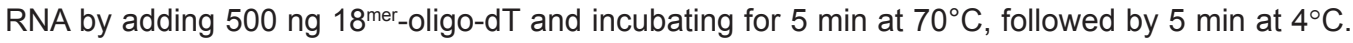
Reverse transcription was conducted using $200 \mathrm{U} \mathrm{Improm}^{\text {TM}}$-II (Promega, Madison, WI, USA), 3 $\mathrm{mM} \mathrm{MgCl}{ }_{2}, 5 \mu \mathrm{M}$ dNTPs, and $40 \mathrm{U}$ RNAse Out (Invitrogen, Carlsbad, CA, USA) in a thermal program at $25^{\circ} \mathrm{C}$ for $5 \mathrm{~min}, 42^{\circ} \mathrm{C}$ for $60 \mathrm{~min}$, and $70^{\circ} \mathrm{C}$ for $15 \mathrm{~min}$.

\section{RT-qPCR}

Quantitative amplification reactions were conducted with reverse-transcribed sample RNAs in 10- $\mu \mathrm{L}$ reactions containing $1 \mu \mathrm{L}$ cDNA 1:10 (v/v) dilution, $0.5 \mathrm{mM}$ of each transcript-specific primer, and $5 \mu \mathrm{L} 2$ X Platinum ${ }^{\circledR}$ SYBR $^{\circledR}$-Green RT-qPCR SuperMix-UDG (Invitrogen). Amplifications were performed in triplicate, with initial incubations at $50^{\circ} \mathrm{C}$ for $2 \mathrm{~min}$ and $95^{\circ} \mathrm{C}$ for $2 \mathrm{~min}$, followed by 40 cycles at $95^{\circ} \mathrm{C}$ for $15 \mathrm{~s}, 60^{\circ} \mathrm{C}$ for $15 \mathrm{~s}$, and $72^{\circ} \mathrm{C}$ for $20 \mathrm{~s}$, with fluorescence detection at the end of the extension cycles. All of the experiments included a non-template control. Primer specificity was determined by melting curve analysis from $72^{\circ}$ to $95^{\circ} \mathrm{C}$, after amplification of the reverse-transcript reactions. The amplification efficiency for each amplicon was determined using serial dilutions $\left(10^{-1}, 10^{-2}\right.$, and $\left.10^{-3} \mathrm{v} / \mathrm{v}\right)$ of cDNA pooled from all of the tissue and organ samples. Data acquisition was performed using Rotor-Gene ${ }^{\circledR}$ Real-Time Analysis 6.0 (Corbett Research, Sydney, Australia) that provided the quantification cycle $\left(C_{q}\right)$ and efficiency $(E)$.

\section{Stability of reference genes}

The stability of the reference genes in the two experiments was estimated using the software geNorm (Vandesompele et al., 2002) and NormFinder (Andersen et al., 2004). In both programs, $C_{\mathrm{q}}$ values were transformed into relative quantities $(\mathrm{Q})$, estimated by:

$$
\mathrm{Q}=E^{(\mathrm{Cq} \text { minimum }-\mathrm{Cq} \text { sample })}
$$

Equation 1

where $E$ is the amplification efficiency, and the minimum $C_{q}$ was the lowest $C_{q}$ (sample with more expression).

\section{RESULTS}

\section{Primer specificity}

All of the amplicons exhibited a single peak, indicating the specificity of the primer pairs 
(data not shown). The amplification efficiency of the gene-specific primer pairs was determined using a pool of sample cDNA from various tissues and organs obtained from healthy plants, and varied from $1.8(P S I)$ to $2.1(M D H)$ (Table 1). The correlation coefficient $\left(\mathrm{R}^{2}\right)$, which is a measure of replicate reproducibility of the standard curve, was equal to or above 0.95 for all of the reactions (Table 1 ).

Table 1. Primer sequences for reference gene candidates, indicating amplicon size (base pairs) and the estimated amplification efficiency and correlation efficiency (R2) used to determine gene expression stability by reverse transcription quantitative polymerase chain reaction.

\begin{tabular}{|c|c|c|c|c|}
\hline Gene & Primer & Amplicon size (bp) & Efficiency & R2 \\
\hline \multirow[t]{2}{*}{ ACT } & CCGAGCGTGGTTATTCTTTC & & & \\
\hline & CTGAGCTGGTCTTTGCTGTCT & 123 & 1.87 & 0.95 \\
\hline \multirow{2}{*}{ EF } & CCACATTGCTGTCAAGTTTTCT & & & \\
\hline & CCATTCGGCATTTCCATTT & 106 & 2.00 & 0.99 \\
\hline \multirow[t]{2}{*}{ IF3 } & CAAGACGCTGATTGTCCTCTC & & & \\
\hline & CTGAATTGCTTGCTCAAAACC & 121 & 1.82 & 0.99 \\
\hline \multirow[t]{2}{*}{ IF5A } & ACTGAAACCGGAAACACCAA & & & \\
\hline & TTTCCTTCAGCAAACCCATC & 89 & 1.87 & 0.99 \\
\hline \multirow[t]{2}{*}{ GAPDH } & TGACCACTGTCCATTCCATC & & & \\
\hline & GCAGGCAAAACCTTACCAAC & 145 & 1.87 & 0.99 \\
\hline \multirow[t]{2}{*}{$M D H$} & ТСТССАТССАССААСТСТСС & & & \\
\hline & GCTCCCAATACAGCCACCT & 108 & 2.1 & 1.00 \\
\hline \multirow[t]{2}{*}{ PHS } & СCTCTTTGGAGTTTTTGATGGT & & & \\
\hline & TCCGAGTCTGTGTGGCTGT & 147 & 1.97 & 0.98 \\
\hline \multirow[t]{2}{*}{ PSI } & GCATTGGATGAGATCGAAGAA & & & \\
\hline & CACATTCCTGGCACACAAAG & 96 & 1.8 & 0.99 \\
\hline \multirow[t]{2}{*}{ Rp/35 } & GAAGGCGGCTTTGAGAGAA & & & \\
\hline & ATGCCTGATGCTTGGTGAG & 107 & 1.98 & 0.99 \\
\hline \multirow[t]{2}{*}{$T U B$} & TTTGTGACATCCCTCCGACT & & & \\
\hline & TСАСССТССТGAACATTTCC & 111 & 1.98 & 0.99 \\
\hline \multirow[t]{2}{*}{$U B Q$} & GACCCTCGCCGACTACAAT & & & \\
\hline & TCTGAACTTTCСACСТCСAAA & 129 & 2.02 & 0.99 \\
\hline
\end{tabular}

$A C T$, actin; $E F$, elongation factor; $G A P D H$, glyceraldehyde 3-phosphate dehydrogenase; $M D H$, malate dehydrogenase; $P H S$, phosphatase; $P S I$, PSI reaction center subunit III; Rp/35, ribosomal protein L35; IF3, translation initiation factor 3; IF5A, translation initiation factor $5 \mathrm{~A}$; UBQ, ubiquitin; $T U B$, tubulin.

\section{Profile of stability variation between reference genes}

For the evaluation of reference gene expression profiles using cDNA from healthy tissues and organs, the lowest $\mathrm{C}_{\mathrm{q}}$ value was obtained for GAPDH in the fruit pulp sample (15.65), and the highest was for $A C T$ in the fruit peel (31.19) (Figure 1). For the expression analysis of leaf samples from HLB-infected plants, the lowest $C_{q}$ was obtained for $P S I$ (16.42) and the highest was for ACT (26.02) (Figure 2).

In the experiment with samples from non-infected plants, the genes with the largest variation range (least stable) for $\mathrm{C}_{\mathrm{q}}$ among the samples were $P S I\left(11.21 \mathrm{C}_{\mathrm{qs}}\right), A C T\left(10.66 \mathrm{C}_{\mathrm{qs}}\right)$, and $\operatorname{MDH}\left(9.01 \mathrm{C}_{\mathrm{qs}}\right)$, and the least variable for the same samples were $E F\left(5.19 \mathrm{C}_{\mathrm{qs}}\right), R p / 35\left(5.57 \mathrm{C}_{\mathrm{qs}}\right)$, and IF5A (5.71 $\mathrm{C}_{\mathrm{qs}}$ ) (Figure 1). For the samples from infected plants, the genes that exhibited the largest variation in expression were $A C T\left(2.19 \mathrm{C}_{\mathrm{qs}}\right), G A P D H\left(1.61 \mathrm{C}_{\mathrm{qs}}\right)$, and $P S I\left(0.92 \mathrm{C}_{\mathrm{qs}}\right)$, and the least variable were $\mathrm{MDH}\left(0.23 \mathrm{C}_{\mathrm{qs}}\right), R p / 35\left(0.25 \mathrm{C}_{\mathrm{qs}}\right)$, and $P H S\left(0.28 \mathrm{C}_{\mathrm{qs}}\right)$ (Figure 2).

\section{Analysis of reference gene stability}

Large differences in expression were observed among the 11 reference gene candidates in the various samples of 'Sanguínea de Mombuca' (Figures 1 and 2). 


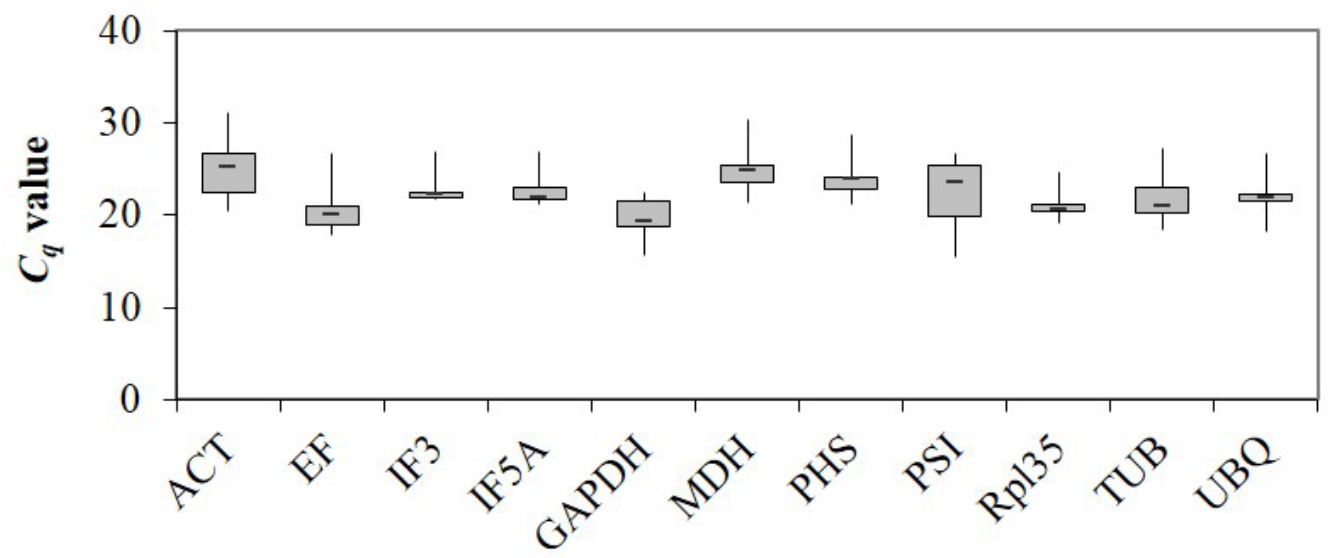

Figure 1. Box-whisker plot of quantification cycle $(\mathrm{Cq})$ variation in samples of healthy 'Sanguínea de Mombuca' plants (various tissues and organs) estimated by reverse transcription quantitative polymerase chain reaction. The inner line indicates the median and the box the 25 and $75 \%$ percentiles as lower and upper limits; vertical lines represent the maximum and minimum observed values. $A C T$, actin; $E F$, elongation factor; $G A P D H$, glyceraldehyde 3-phosphate dehydrogenase; $M D H$, malate dehydrogenase; PHS, phosphatase; PSI, PSI reaction center subunit III; $R p / 35$, ribosomal protein L35; IF3, translation initiation factor 3; IF5A, translation initiation factor $5 \mathrm{~A}$; UBQ, ubiquitin; TUB, tubulin.

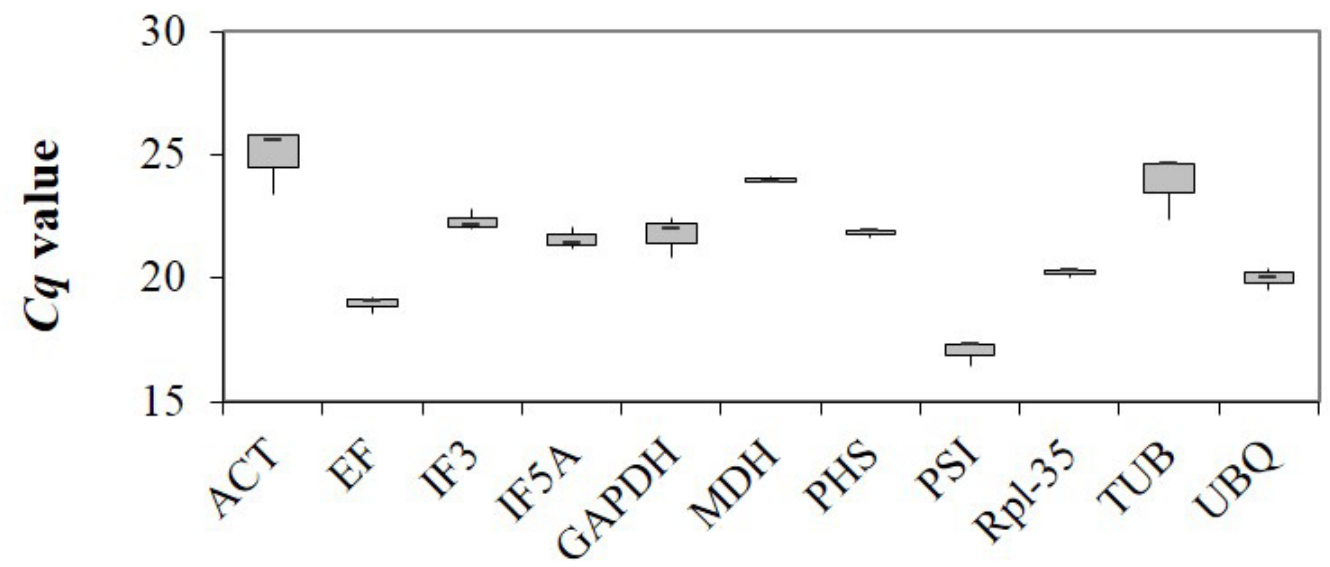

Figure 2. Box-whisker plot of quantification cycle $(\mathrm{Cq})$ variation in samples of leaves of 'Sanguínea de Mombuca' plants infected with Candidatus liberibacter asiaticus estimated by reverse transcription quantitative polymerase chain reaction. The inner line indicates the median and the box the 25 and $75 \%$ percentiles as lower and upper limits; vertical lines represent the maximum and minimum observed values. $A C T$, actin; $E F$, elongation factor; GAPDH, glyceraldehyde 3-phosphate dehydrogenase; $M D H$, malate dehydrogenase; PHS, phosphatase; PSI, PSI reaction center subunit III; Rp/35, ribosomal protein L35; IF3, translation initiation factor 3; IF5A, translation initiation factor $5 \mathrm{~A}$; $U B Q$, ubiquitin; $T U B$, tubulin.

Gene stability analysis using geNorm indicated that the most stable genes among the tested samples were IF3, Rp/35, and IF5A, with M values of $1.61,1.69$, and 1.76, respectively (Table 2). The most stable pair of reference genes recommended was IF3 and Rp/35 (Figure 3), and the least stable was $A C T$ and $P S I$, with M values of 2.82 and 3.41 , respectively (Table 2). 
Table 2. Expression stability and ranking of $M$ values for reference gene candidates using samples from noninfected 'Sanguínea de Mombuca' plants (various tissues and organs) and from leaves of plants infected with Candidatus liberibacter asiaticus, based on geNorm.

\begin{tabular}{|c|c|c|c|c|c|c|c|c|c|c|c|}
\hline & $A C T$ & $E F$ & GAPDH & IF3 & IF5A & $M D H$ & PHS & PSI & Rp/35 & TUB & UQB \\
\hline Non-infected tissues/organs & 2.82 & 2.12 & 2.47 & 1.61 & 1.76 & 2.22 & 1.81 & 3.41 & 1.69 & 2.14 & 1.95 \\
\hline Infected Leaves & 1.06 & 0.60 & 0.75 & 0.54 & 0.59 & 0.50 & 0.53 & 0.82 & 0.52 & 1.01 & 0.76 \\
\hline
\end{tabular}

$A C T$, actin; $E F$, elongation factor; GAPDH, glyceraldehyde 3-phosphate dehydrogenase; $M D H$, malate dehydrogenase; $P H S$, phosphatase; PSI, PSI reaction center subunit III; Rp/35, ribosomal protein L35; IF3, translation initiation factor 3; IF5A, translation initiation factor $5 A$; UBQ, ubiquitin; TUB, tubulin.

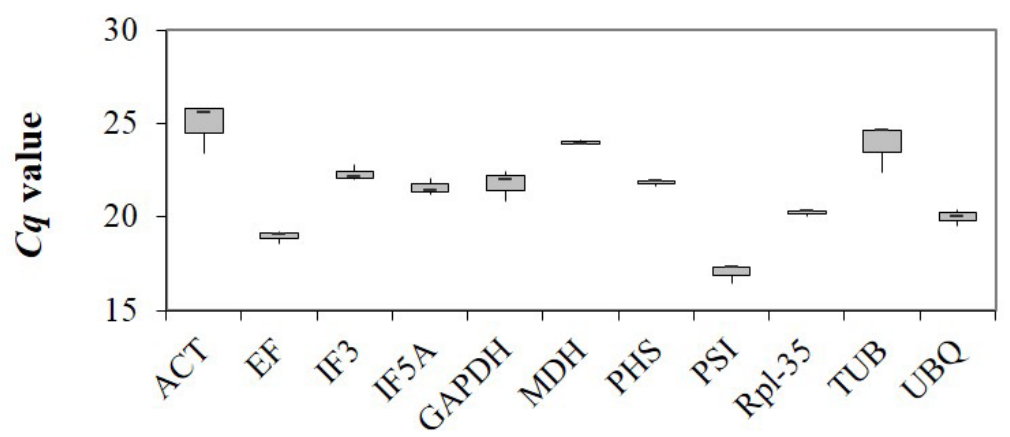

Figure 3. Mean expression stability values (M) and reference gene candidates estimated by geNorm from tissues and organs of non-infected 'Sanguínea de Mombuca' plants. $A C T$, actin; $E F$, elongation factor; GAPDH, glyceraldehyde 3-phosphate dehydrogenase; $M D H$, malate dehydrogenase; PHS, phosphatase; PSI, PSI reaction center subunit III; $R p / 35$, ribosomal protein $L 35$; IF3, translation initiation factor 3; IF5A, translation initiation factor $5 \mathrm{~A}$; UBQ, ubiquitin; TUB, tubulin.

When the reference genes were tested in samples from infected plants and analyzed using geNorm, the most stable genes were $M D H, R p / 35$, and $P H S$, with $\mathrm{M}$ values of $0.5,0.52$, and 0.53 , respectively. The most stable pair of reference genes from the infected samples was $M D H$ and $R p / 35$ (Figure 4), and the least stable was TUB $(\mathrm{M}=1.01)$ and $A C T(\mathrm{M}=1.06)($ Table 2$)$.

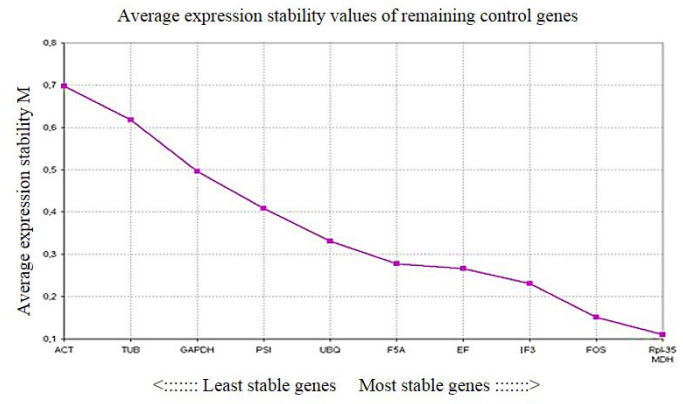

Figure 4. Mean expression stability values $(M)$ and reference gene candidates estimated by geNorm from leaves of 'Sanguínea de Mombuca' plants infected with Candidatus liberibacter asiaticus. ACT, actin; EF, elongation factor; GAPDH, glyceraldehyde 3-phosphate dehydrogenase; $M D H$, malate dehydrogenase; PHS, phosphatase; PSI, PSI reaction center subunit III; Rp/35, ribosomal protein L35; IF3, translation initiation factor 3; IF5A, translation initiation factor $5 \mathrm{~A}$; UBQ, ubiquitin; TUB, tubulin. 
To determine the appropriate number of reference genes under the conditions tested, geNorm calculated the pairwise variation between genes, as follows:

$$
V_{n} / V_{n+1}
$$

Equation 2

This variation was calculated from the normalization factors derived from the gradual inclusion of a reference gene, to determine the addition effect of each gene in the normalization of the experiment. Vandesompele et al. (2002) considered that for values below 0.15 , the inclusion of an additional reference gene was not necessary for normalization. When we analyzed the ideal number of reference genes for the biological conditions tested, the values estimated by geNorm were above 0.15 :

$$
\mathrm{V}_{\mathrm{n}} / \mathrm{V}_{\mathrm{n}+1}=0.197
$$

Equation 3

geNorm suggested the inclusion of up to six reference genes to normalize expression for the tissue and organ samples of 'Sanguínea de Mombuca' (Figure 5), but geNorm suggested that three reference genes were sufficient to normalize gene expression for leaf samples from infected plants, with a pairwise variation of 0.055 (Figure 6).

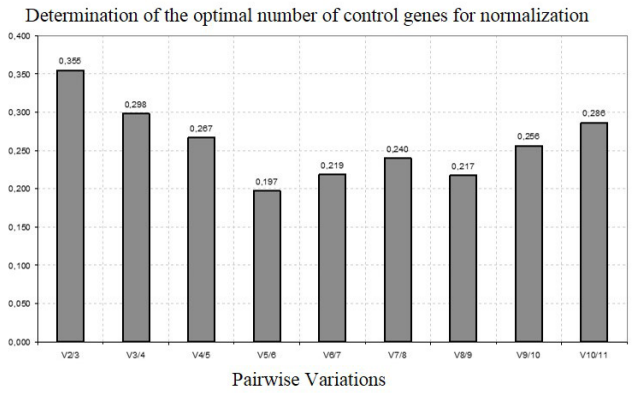

Figure 5. Determination of the optimal number of reference genes required to estimate relative expression based on samples (tissues and organs) of non-infected 'Sanguínea de Mombuca' plants. Pairwise variations $(V n / V n+1)$ were estimated by geNorm based on two sequential normalization factors (NF), according to the gradual introduction of the next least stable candidate.

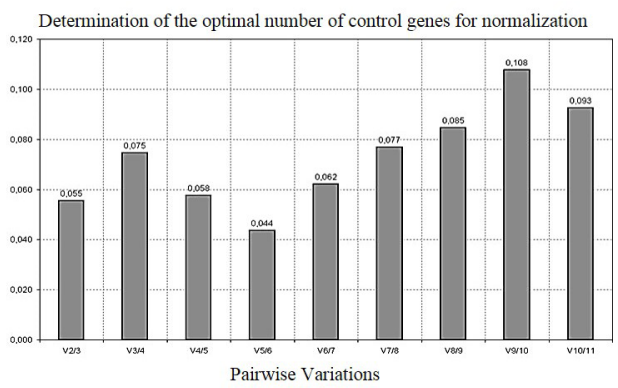

Figure 6. Determination of the optimal number of reference genes required to estimate relative expression based on leaf samples of 'Sanguínea de Mombuca' plants infected with Candidatus liberibacter asiaticus. Pairwise variations $(V n / V n+1)$ were estimated by geNorm based on two sequential normalization factors (NF), according to the gradual introduction of the next least stable candidate. 
Based on the analysis of stability using NormFinder, the most stable genes identified were IF3, with a stability value of $0.09, R p / 35$ with 0.44 , and IF5A with 0.47 . The least stable genes were $A C T$ and $P S I$, with stability values of 1.68 and 2.16 , respectively (Table 3 ). When samples derived from infected plants were analyzed for reference gene stability using NormFinder, the most stable genes identified were $M D H, R p / 35$, and IF3 $(0.04,0.05$, and 0.06 , respectively), and the least stable were TUB and $A C T$ ( 0.66 and 0.70 , respectively) (Table 3$)$.

Table 3. Expression stability and ranking of $M$ values for reference gene candidates using samples from noninfected 'Sanguínea de Mombuca' plants (various tissues and organs) and from leaves of plants infected with Candidatus liberibacter asiaticus, based on NormFinder.

\begin{tabular}{|c|c|c|c|c|c|c|c|c|c|c|c|}
\hline & $A C T$ & $E F$ & GAPDH & IF3 & IF5A & $M D H$ & PHS & PSI & Rp/35 & TUB & $U Q B$ \\
\hline Von-infected tissues/organs & 1.68 & 1.10 & 1.40 & 0.09 & 0.47 & 1.22 & 0.70 & 2.16 & 0.44 & 1.02 & 0.85 \\
\hline Infected Leaves & 0.70 & 0.29 & 0.36 & 0.06 & 0.23 & 0.04 & 0.20 & 0.48 & 0.05 & 0.66 & 0.47 \\
\hline
\end{tabular}

$A C T$, actin; $E F$, elongation factor; GAPDH, glyceraldehyde 3-phosphate dehydrogenase; $M D H$, malate dehydrogenase; Ii, phosphatase; PSI, PSI reaction center subunit III; Rp/35, ribosomal protein L35; IF3, translation initiation factor 3; IF5A, translation initiation factor $5 \mathrm{~A}$; UBQ, ubiquitin; TUB, tubulin.

\section{DISCUSSION}

RT-qPCR is one of the most widely used methods of estimating gene expression (Liu et al., 2010), and has become the method of choice for transcript profiling. Despite this, the use of RT-qPCR requires various standardizations to avoid inaccuracy and lack of precision. Among the standardizations, the selection of reference genes is a critical decision. Reference gene expression must exhibit minimal variation between the tissues and biological or ontogenetic conditions tested, and the optimal number of reference genes must be experimentally determined (Vandesompele et al., 2002; Bustin et al., 2009).

Our analyses of 11 candidate reference genes for a red-fleshed orange cultivar using two software programs (geNorm and NormFinder) produced convergent results. When the samples from the various tissues and organs of 'Sanguínea de Mombuca' were analyzed, both programs selected IF3, Rp/35, and IF5A as the most stable genes, while ACT and PSI were the least stable. Therefore, these three stable genes are recommended for the normalization of gene expression for this Citrus cultivar under the conditions tested (Figure 3 and Table 2). When the gene expression stability of samples derived from C. liberibacter asiaticus-infected plants was analyzed, the results from both programs were again convergent, but geNorm identified $M D H, R p l 35$, and $P H S$ as the most stable genes, whereas NormFinder identified $M D H, R p / 35$, and IF3 as the most stable, with PHS as the fourth most stable. This discrepancy between the programs can be explained by the fact that the geNorm algorithm is sensitive to genes that are co-regulated or have similar expression patterns, which could have masked the real stability value of some of the genes (Andersen et al., 2004). Based on this assumption, it can be concluded that the third most suitable gene for the standardization of expression in infected plants would be IF3, which was suggested by NormFinder. Regarding the least stable genes, both programs identified ACT and TUB as the least suitable for the normalization of gene expression under these conditions.

Mafra et al. (2012) analyzed the stability of 15 candidate reference genes in various tissues and organs of Citrus plants infected with several pathogens, including C. liberibacter and Xylella fastidiosa. FBOX (F-box family protein, which regulates cellular processes such as cell cycle transition, transcriptional regulation, and signal transduction), SAND (SAND protein family, 
which regulates intracellular vesicle transport), GAPC2 (GAPDH C2, which participates in the metabolism of glucose), and UPL7 (ubiquitin ligase 7 protein, which functions in protein trafficking) were demonstrated to be the most stable in all of the conditions and samples tested by Mafra et al. (2012). When the analysis was conducted with samples from C. liberibacter-infected plants, TUB was the least stable gene, which is similar to what we observed in the present study.

Genes that encode initiation factors have been previously indicated as reference genes (Garg et al., 2010; Lin and Lai, 2010; Schmidt and Delaney, 2010). In this study, stability analysis by both programs indicated that IF3 was the most stable, but only the third most stable when using infected leaves according to NormFinder. IF5A, which was the third most stable gene using samples from non-infected tissues and organs, has been reported as one of the most stable in experiments with flax (Huis et al., 2010).

The stability of genes that encode ribosomal proteins, such as $R p / 35$, has been evaluated in many studies, with positive results (Calsa and Figueira, 2007; Schmidt and Delaney, 2010; Pinheiro et al., 2011; Yan et al., 2012). The stability of seven reference gene candidates was analyzed in six Citrus genotypes by Yan et al. (2012), and 18SrRNA was found to be one of the most stable. The expression stability of 10 candidates was evaluated in various tissues of Theobroma cacao by Pinheiro et al. (2011), and Rp/35 was one of the most stable and suitable for the normalization of gene expression when outgrowing shoots were infected with the basidiomycete, Moniliophthora perniciosa. The same gene exhibited stability in infected and healthy tissues of 'Sanguínea de Mombuca' in the present study.

$\mathrm{MDH}$ was considered one of the most stable genes by NormFinder and geNorm, and formed the best pair with $R p / 35$ for samples derived from tissues of 'Sanguínea de Mombuca' infected with $C$. liberibacter asiaticus. In experiments with cacao, $M D H$ also formed the best combination of reference genes with Rp/35 in tissues inoculated with M. perniciosa (Pinheiro et al., 2011). ACT has been evaluated as a gene reference in various gene expression studies (Liu et al., 2010; Chen et al., 2011), and was considered highly stable when analyzed in various Citrus genotypes (Yan et al., 2012). However, in the present study, ACT was one of the least stable genes, in both non-infected and infected plants. The expression instability of ACT under specific conditions has been reported in other studies (Guénin et al., 2009; Huis et al., 2010; Rajarapu et al., 2012). Tubulin has also been shown to be unstable in some Citrus genotypes (Yan et al., 2012), during the developmental stages of flax (Huis et al., 2010), and in Orobanche ramosa (González-Verdejo et al., 2008).

\section{Conflicts of interest}

The authors declare no conflict of interest.

\section{ACKNOWLEDGMENTS}

The authors (T.T. Pinheiro, D.S. Nishimura, and A. Figueira) are grateful for the fellowships provided by CNPq, and F.B. De Nadai is grateful for the fellowship provided by CAPES.

\section{REFERENCES}

\footnotetext{
Andersen CL, Jensen JL and Orntoft TF (2004). Normalization of real-time quantitative reverse transcription-PCR data: a model-based variance estimation approach to identify genes suited for normalization, applied to bladder and colon cancer data sets. Cancer Res. 64: 5245-5250.
} 
Aptekmann NC and Cesar TB (2013). Long-term orange juice consumption is associated with low LDL-cholesterol and apolipoprotein B in normal and moderately hypercholesterolemic subjects. Lipids Health Dis. 12: 1-10.

Bomal C, Bedon F, Caron S, Mansfield SD, et al. (2008). Involvement of Pinus taeda MYB1 and MYB8 in phenylpropanoid metabolism and secondary cell wall biogenesis: a comparative in planta analysis. J. Exp. Bot. 59: 3925-3939.

Bové JM (2006). Huanglongbing: a destructive, newly-emerging, century-old disease of citrus. J. Plant Pathol. 88: 7-37.

Bustin SA, Benes V, Garson JA, Hellemans J, et al. (2009). The MIQE guidelines: minimum information for publication of quantitative real-time PCR experiments. Clin. Chem. 55: 611-622.

Calsa TJ and Figueira A (2007). Serial analysis of gene expression in sugarcane (Saccharum spp.) leaves revealed alternative C4 metabolism and putative antisense transcripts. Plant Mol. Biol. 63: 745-762.

Chen L, Zhong HY, Kuang JF, Li JG, et al. (2011). Validation of reference genes for RT-qPCR studies of gene expression in banana fruit under different experimental conditions. Planta 234: 377-390.

Coletta-Filho HD, Carlos EF, Alves KCS, Pereira MAR, et al. (2010). In planta multiplication and graft transmission of 'Candidatus liberibacter asiaticus' revealed by real-time PCR. Eur. J. Plant Pathol. 126: 53-60.

Dheda K, Huggett JF, Chang JS, Kim LU, et al. (2005). The implications of using an inappropriate reference gene for real-time reverse transcription PCR data normalization. Anal. Biochem. 344: 141-143.

Die JV, Román B, Nadal S and González-Verdejo Cl (2010). Evaluation of candidate reference genes for expression studies in Pisum sativum under different experimental conditions. Planta 232: 145-153.

Folimonova SY, Robertson CJ, Garnsey SM, Gowda S, et al. (2009). Examination of the responses of different genotypes of citrus to Huanglongbing (citrus greening) under different conditions. Phytopathology 99: 1346-1354.

Gachon C, Mingam A and Charrier B (2004). Real-time PCR: what relevance to plant studies? J. Exp. Bot. 55: 1445-1454.

Galli V, Messias RS, Silva SDA and Rombaldi CV (2013). Selection of reliable reference genes for quantitative real-time polymerase chain reaction studies in maize grains. Plant Cell Rep. 32: 1869-1877.

Garg R, Sahoo A, Tyagi AK and Jain M (2010). Validation of internal control genes for quantitative gene expression studies in chickpea (Cicer arietinum L.). Biochem. Biophys. Res. Commun. 396: 283-288.

González-Verdejo CI, Die JV, Nadal S, Jiménez-Marín A, et al. (2008). Selection of housekeeping genes for normalization by realtime RT-PCR: Analysis of Or-MYB1 gene expression in Orobanche ramose development. Anal. Biochem. 379: 176-171.

Gottwald TR (2010). Current epidemiological understanding of citrus Huanglongbing. Annu. Rev. Phytopathol. 48: 119-139.

Guénin S, Mauriat M, Pelloux J, Wuytswinkel OV, et al. (2009). Normalization of qRT-PCR data: the necessity of adopting a systematic, experimental conditions-specific, validation of references. J. Exp. Bot. 2: 487-493.

Halbert SE and Manjunath KL (2004). Asian citrus psyllids (Sternorrhyncha: Psyllidae) and greening disease of citrus: a literature review and assessment of risk in Florida. Florida Entomol. 87: 330-353.

Huggett J, Dheda K, Bustin S and Zumla A (2005). Real-time RT-PCR normalisation; strategies and considerations. Genes Immun. 6: 279-285.

Huis R, Hawkins S and Neutelings $G$ (2010). Selection of reference genes for quantitative gene expression normalization in flax (Linum usitatissimum L.). BMC Plant Biol. 10: 1-14.

Kou SJ, Wu XM, Liu Z, Liu YK, et al. (2012). Selection and validation of suitable reference genes for miRNA expression normalization by quantitative RT-PCR in citrus somatic embryogenic and adult tissues. Plant Cell Rep. 31: 2151-2163.

Latado RR, Nishimura DS, Leao HC and Sylos CM (2008). Laranjas de polpa vermelha: caracterização de frutos e do suco dos frutos. In: Anais do $20^{\circ}$ Congresso Brasileiro de Fruticultura, Vitória.

Lin YL and Lai ZX (2010). Reference gene selection for GPCR analysis during somatic embryogenesis in longan tree. Plant Sci. 178: 359-365.

Liu JJ, Zamani A and Ekramoddoullah AK (2010). Expression profiling of a complex thaumatin-like protein family in western white pine. Planta 231: 637-651.

Liu Q, Xu J, Liu Y, Zhao X, et al. (2007). A novel bud mutation that confers abnormal patterns of lycopene accumulation in sweet orange fruit (Citrus sinensis L. Osbeck). J. Exp. Bot. 58: 4161-4171.

Mafra V, Kubo KS, Alves-Ferreira M, Ribeiro-Alves M, et al. (2012). Reference genes for accurate transcript normalization in citrus genotypes under different experimental conditions. PLoS One 7: 1-11.

Neves MF, Trombin VG, Milan P, Lopes F, et al. (2010). O retrato da citricultura brasileira. Markstrat, Piracicaba.

Pattison RJ, Csukasi F, Zheng Y, Fei Z, et al. (2015). Comprehensive tissue-specific transcriptome analysis reveals distinct regulatory programs during early tomato fruit development. Plant Physiol. 168: 1684-1701.

Pinheiro TT, Litholdo CGJ, Sereno ML, Leal MLJ, et al. (2011). Establishing references for gene expression analyses by RTqPCR in Theobroma cacao tissues. Genet. Mol. Res. 10: 3291-3305.

Rajarapu SP, Mamidala P and Mittapalli O (2012). Validation of reference genes for gene expression studies in the emerald ash borer (Agrilus planipennis). Insect Sci. 19: 41-46.

Rozen S and Skaletsky HJ (2000). Primer3: bioinformatics methods and protocols. In: Methods in molecular biology (Krawetz S and Misener S, eds.). Human Press, New Jersey, pp. 365-386. http://bioinfo.ut.ee/primer3. 
Schmidt GW and Delaney SK (2010). Stable internal reference genes for normalization of real-time RT-PCR in tobacco (Nicotiana tabacum) during development and abiotic stress. Mol. Genet. Genomics 283: 233-241.

Schmittgen T and Zakrajsek BA (2000). Effect of experimental treatment on housekeeping gene expression: validation by realtime, quantitative RT-PCR. J. Biochem. Biophys. Methods 46: 69-81.

Shen Y, Venu RC, Nobuta K, Xu X, et al. (2011). Transcriptome dynamics through alternative polyadenylation in developmental and environmental responses in plants revealed by deep sequencing. Genome Res. 9: 1478-1486.

Shokrollah H, Abdullah TL, Sijam K, Abdullah SNA, et al. (2009). Differential reaction of citrus species in Malaysia to Huanglongbing (HLB) disease using grafting method. Am. J. Agr. Biol. Sci. 4: 32-38.

Silveira JQ, Cesar TB, Manthey JA, Baldwin EA, et al. (2014). Pharmacokinetics of flavone glycosides after ingestion of single doses of fresh-squeezed orange juice versus commercially processed orange juice in healthy humans. J. Agric. Food Chem. 62: 12576-12584.

Small BC, Murdock CA, Bilodeau-Bourgeois L, Peterson BC, et al. (2008). Stability of reference genes for real-time PCR analyses in channel catfish (Ictalurus punctatus) tissues under varying physiological conditions. Comp. Biochem. Physiol. B Biochem. Mol. Biol. 151: 296-304.

Tao NG, Cheng YJ, Xu J, Xu Q, et al. (2004). An effective protocol for the isolation of RNA from the pulp of ripening citrus fruits. Plant Mol. Biol. Rep. 22: 305a-305f.

Vandesompele J, Preter KD, Pattyn F, Poppe B, et al. (2002). Accurate normalization of real-time quantitative RT-PCR data by geometric averaging of multiple internal control genes. Genome Biol. 3: 1-12.

Yan J, Yuan F, Long G, Qin L, et al. (2012). Selection of reference genes for quantitative real-time RT-PCR analysis in citrus. Mol. Biol. Rep. 39: 1831-1838. 